\title{
Parametric Study of Heating and Cooling Capacity of Interior Thermally Active Panels
}

\author{
Daniel Kalús', Zuzana Straková1*, Matej Kubica \\ ${ }^{1}$ Department of Building Services, Faculty of Civil Engineering, Slovak University of Technology in Bratislava, 81005 Bratislava, \\ Radlinského 11, Slovakia \\ * Corresponding author, e-mail: zuzana.strakova@stuba.sk
}

Received: 23 November 2020, Accepted: 15 January 2021, Published online: 05 July 2021

\begin{abstract}
ITAP panels - interior thermally active panels with an integrated active surface in an innovative way combine existing building and energy systems into one compact unit, and thus create combined building and energy systems. These are building structures with an internal energy source. Low heat losses, respectively, thermal gains predestine for energy-efficient buildings the application of lowtemperature heating/high-temperature cooling systems such as large-area floor, wall, and ceiling heating/cooling. The main benefit of ITAP panels is the possibility of unified and prefabricated production. At the same time, they represent a reduction of production costs due to their technological process of production, a reduction of assembly costs due to a reduction of steps during implementation on the construction site and a reduction of implementation time due to their method of application.
\end{abstract}

\section{Keywords}

thermally active panels, integrated active surface, large-area radiant low-temperature heating temperature, high-temperature cooling, mathematical-physical model, parametric study

\section{Introduction}

ITAP panels - interior thermally active panels with an integrated active surface are formed by a tubular or capillary energy system integrated in the thermal insulation part of a panel and a thermally active surface formed by a thermally conductive material (e.g., thin layer plaster, plasterboard, or sheet metal). They are applied in the same way as previously known panels with integrated tubular or capillary systems (e.g., in SD boards). ITAP panels are protected by European patent EP 2572057 B1 [1] from 15.10.2014 [2]. We focused our research in this area on the possibilities of application of ITAP panels for large-area low-temperature heating and high-temperature cooling with heat/cold sources based on RES [1, 2, 3-6]. The subject of the research described in this paper is a parametric study of the method of heat/cold dissipation in a perimeter wall and interior wall fragment with concealed tube energy system and ITAP panels, optimization of appropriate thermal insulation thickness, tube dimensions and spacing of interior thermally active panels with an integrated active surface [1, 2, 3-6].

\section{Research methodology and methods}

To solve the given research questions we have chosen the method of a parametric study. A mathematical-physical model of the perimeter wall with an ITAP panel was created. Stationary (time-stabilized) parametric studies were performed, where the following parameters changed: thickness of the thermal insulation (ITAP panel), spacing and dimension of the tubes, temperature gradient of the heat transfer medium and temperature in the interior, exterior, and adjacent room, respectively. All these parametric studies were performed at boundary conditions representing both winter and summer, $[2,3,7,8]$.

\subsection{Theory of calculation of large-area radiant heating} Calculation of the radiant heating surface is based on the assumption that the average surface temperature of the radiant heating surface does not exceed hygienically permissible values, while the heat output of the radiant heating surface will cover the heat losses of the heated space. Modified calculation for radiant hot water heating, $[7,9,10]$. Thermal permeability of the layer above/in front of the tubes $\Lambda_{a}\left(\mathrm{~W} /\left(\mathrm{m}^{2} . \mathrm{K}\right)\right)$ is calculated as in Eq. (1): 


$$
\Lambda_{a}=\frac{1}{\sum \frac{a}{\lambda_{a}}+\frac{1}{h_{p}}},
$$

where: $a$ is thickness of the layer above/in front of the tubes (m), $\lambda_{a}$ is thermal conductivity coefficient of the material of the respective layer $\left(\mathrm{W} /\left(\mathrm{m}^{2} . \mathrm{K}\right)\right), h_{p}$ is heat transfer coefficient $\left(\mathrm{W} /\left(\mathrm{m}^{2} \cdot \mathrm{K}\right)\right)$.

Thermal permeability of the layer under/behind the tubes $\Lambda_{b}\left(\mathrm{~W} /\left(\mathrm{m}^{2} . \mathrm{K}\right)\right)$ is calculated as in Eq. (2):

$$
\Lambda_{b}=\frac{1}{\sum \frac{b}{\lambda_{b}}+\frac{1}{h_{p}}},
$$

where: $b$ is thickness of the layer under/behind the tubes (m), $\lambda_{b}$ is thermal conductivity coefficient of the material of the respective layer $\left(\mathrm{W} /\left(\mathrm{m}^{2} . \mathrm{K}\right)\right), h_{p}$ is heat transfer coefficient $\left(\mathrm{W} /\left(\mathrm{m}^{2} \cdot \mathrm{K}\right)\right)$.

Coefficient characterizing the heating plate in terms of heat dissipation $m\left(\mathrm{~m}^{-1}\right)$ is calculated as in Eq. (3):

$$
m=\sqrt{\frac{2 \cdot\left(\Lambda_{a}+\Lambda_{b}\right)}{\pi^{2} \cdot \lambda_{d} \cdot d}},
$$

where: $\Lambda_{a}$ is thermal permeability of the layer above/in front of the tubes $\left(\mathrm{W} /\left(\mathrm{m}^{2} \cdot \mathrm{K}\right)\right), \Lambda_{b}$ is thermal permeability of the layer under/behind the tubes $\left(\mathrm{W} /\left(\mathrm{m}^{2} . \mathrm{K}\right)\right), \lambda_{d}$ is thermal conductivity of the material of the layer in which the tubes are embedded $\left(\mathrm{W} /\left(\mathrm{m}^{2} \cdot \mathrm{K}\right)\right), d$ is tube diameter $(\mathrm{m})$.

Surface temperature of the heating surface $\theta_{p}\left({ }^{\circ} \mathrm{C}\right)$ is calculated as in Eq. (4):

$\theta_{p}-\theta_{i}=\frac{\Lambda_{a}}{h_{p}}\left(\theta_{m}-\theta_{i}\right) \frac{\operatorname{tgh}\left(m \cdot \frac{L}{2}\right)}{m \cdot \frac{L}{2}}$,

where: $\theta_{p}$ is floor surface temperature $\left({ }^{\circ} \mathrm{C}\right), \theta_{i}$ is calculated indoor room temperature $\left({ }^{\circ} \mathrm{C}\right), \Lambda_{a}$ is thermal permeability of the layer above/in front of the tubes $\left(\mathrm{W} /\left(\mathrm{m}^{2} \cdot \mathrm{K}\right)\right), h_{p}$ is heat transfer coefficient $\left(\mathrm{W} /\left(\mathrm{m}^{2} . \mathrm{K}\right)\right), \theta_{m}$ is average temperature of heating water $\left({ }^{\circ} \mathrm{C}\right), m$ is factor characterizing the heating plate in terms of heat dissipation $\left(\mathrm{m}^{-1}\right), L$ is axial distance of tubes (m).

Specific heat output of the heating surface upwards $q\left(\mathrm{~W} / \mathrm{m}^{2}\right)$ is calculated as in Eq. (5):

$q=h_{p} \cdot\left(\theta_{p}-\theta_{i}\right)$,

where: $h_{p}$ is heat transfer coefficient from the floor upwards $\left(\mathrm{W} /\left(\mathrm{m}^{2} \cdot \mathrm{K}\right)\right), \theta_{p}$ is floor surface temperature $\left({ }^{\circ} \mathrm{C}\right), \theta_{i}$ is calculated indoor room temperature $\left({ }^{\circ} \mathrm{C}\right)$.
Specific heat output of the heating surface downwards $q^{\prime}\left(\mathrm{W} / \mathrm{m}^{2}\right)$ is calculated as in Eq. (6):

$q^{\prime}=\frac{\Lambda_{b}}{\Lambda_{a}} \cdot q$,

where: $\Lambda_{b}$ is thermal permeability of the layer under the tubes $\left(\mathrm{W} /\left(\mathrm{m}^{2} . \mathrm{K}\right)\right), \Lambda_{a}$ is thermal permeability of the layer above the tubes $\left(\mathrm{W} /\left(\mathrm{m}^{2} . \mathrm{K}\right)\right), q$ is specific heat output of the underfloor heating surface upwards $(\mathrm{W} / \mathrm{m} 2)$.

Heating area $S\left(\mathrm{~m}^{2}\right)$ is calculated as in Eq. (7):

$S=\frac{Q_{c}}{h_{p} \cdot\left(\theta_{p}-\theta_{i}\right)}=\frac{Q_{c}}{q+q^{\prime}}$,

where: $Q_{c}$ is total heat loss $(\mathrm{W}), h_{p}$ is heat transfer coefficient from the floor upwards $\left(\mathrm{W} /\left(\mathrm{m}^{2} . \mathrm{K}\right)\right), \theta_{p}$ is floor surface temperature $\left({ }^{\circ} \mathrm{C}\right), \theta_{i}$ is calculated indoor room temperature $\left({ }^{\circ} \mathrm{C}\right), q$ is heat output of the heating surface towards the interior $\left(\mathrm{W} / \mathrm{m}^{2}\right), q^{\prime}$ is heat output of the heating surface towards the exterior $\left(\mathrm{W} / \mathrm{m}^{2}\right)$.

Heat output of the heating surface $Q_{s}(\mathrm{~W})$ is calculated as in Eq. (8):

$Q_{s}=\left(q+q^{\prime}\right) \cdot S_{p}$,

where: $q$ is heat output of the heating surface towards the interior $\left(\mathrm{W} / \mathrm{m}^{2}\right), q^{\prime}$ is heat output of the heating surface towards the exterior $\left(\mathrm{W} / \mathrm{m}^{2}\right), S_{p}$ is heating surface $\left(\mathrm{m}^{2}\right)$.

\subsection{Mathematical-physical model}

As a basis for the parametric study, a mathematical-physical model for concealed large-area heating was made (Figs. 1 and 2) and a mathematical-physical model for ITAP panel (Figs. 3 and 4). Color-differentiated materials can be seen on mathematical-physical models, which consist of characteristic fragments of the perimeter wall and the inner wall with a concealed energy system and ITAP panels. Material characteristics were assigned to individual materials [2, 5-14].

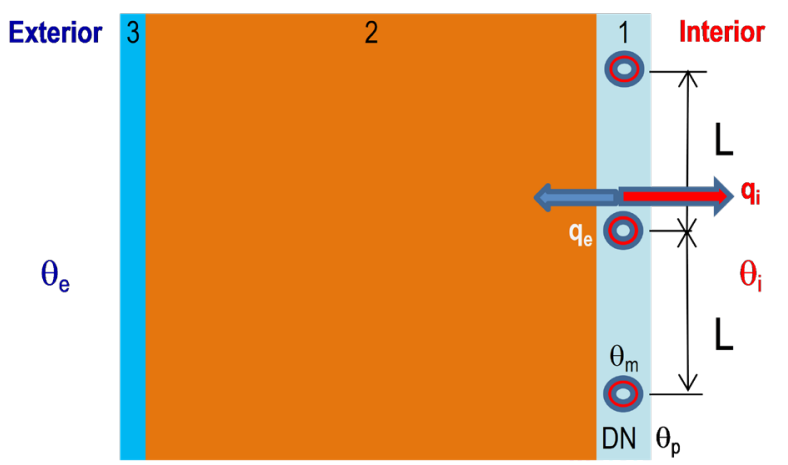

Fig. 1 Mathematical-physical model for concealed large-area heating on the perimeter wall and individual material characteristics according to STN 73 0540-3 [15] 


\subsubsection{Perimeter (external) wall}

Legend for Fig. 1:

$L$ is tube spacing (m), DN is tube dimension (m), $\theta_{m}$ is mean temperature of heating medium $\left({ }^{\circ} \mathrm{C}\right), \theta_{i}$ is interior temperature $\left({ }^{\circ} \mathrm{C}\right), \theta_{e}$ is exterior temperature $\left({ }^{\circ} \mathrm{C}\right), \theta_{p}$ is surface temperature of heating/cooling surface $\left({ }^{\circ} \mathrm{C}\right), q_{i}$ is heat output of the heating surface towards the interior $\left(\mathrm{W} / \mathrm{m}^{2}\right)$, $q^{e}$ is heat output of the heating surface towards the exterior $\left(\mathrm{W} / \mathrm{m}^{2}\right)$.

In Table 1 the values of physical quantities in individual layers of the building structure are given.

\subsubsection{Inner (internal) wall}

Legend for Fig. 2:

$L$ is tube spacing (m), DN is tube dimension (m), $\theta_{m}$ is mean temperature of heating medium $\left({ }^{\circ} \mathrm{C}\right), \theta_{i}$ is interior temperature $\left({ }^{\circ} \mathrm{C}\right), \theta_{i 2}$ is interior temperature in the adjacent room $\left({ }^{\circ} \mathrm{C}\right), \theta_{p}$ is surface temperature of heating/cooling surface $\left({ }^{\circ} \mathrm{C}\right), \theta_{i}$ is heat output of the heating surface towards the interior $\left(\mathrm{W} / \mathrm{m}^{2}\right), \theta_{i 2}$ is heat output of the heating surface towards the adjacent room $\left(\mathrm{W} / \mathrm{m}^{2}\right)$.

Table 1 Mathematical-physical model of large-area radiant heating for perimeter (external) wall [15]

\begin{tabular}{|c|c|c|c|c|c|}
\hline \multirow{2}{*}{ 离 } & Material & 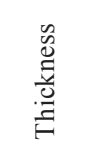 & 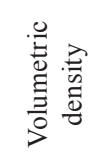 & 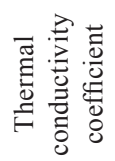 & 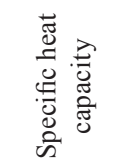 \\
\hline & & $\begin{array}{c}d \\
(\mathrm{~m})\end{array}$ & $\begin{array}{c}\rho \\
\left(\mathrm{kg} / \mathrm{m}^{3}\right)\end{array}$ & $\begin{array}{c}\lambda \\
(\mathrm{W} / \\
(\mathrm{m} \cdot \mathrm{K}))\end{array}$ & $\begin{array}{c}c \\
(\mathrm{~J} /(\mathrm{kg} \cdot \mathrm{K}))\end{array}$ \\
\hline 1 & Interior plaster & $0.010^{*}$ & 1600 & 1.160 & 840 \\
\hline 2 & $\begin{array}{c}\text { Thermal insul. } \\
\text { masonry }\end{array}$ & 0.500 & 650 & 0.058 & 1000 \\
\hline 3 & Exterior plaster & 0.010 & 1300 & 0.800 & 840 \\
\hline
\end{tabular}

* thickness of the layer in front of/behind tubes toward the interior

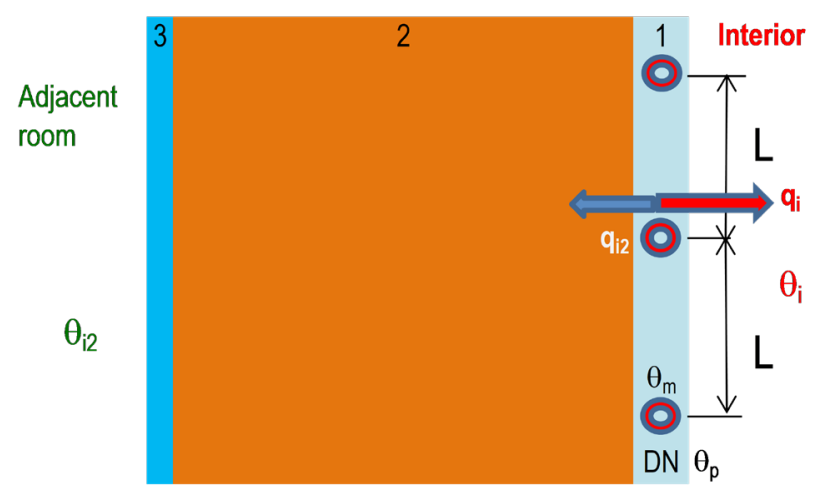

Fig. 2 Mathematical-physical model for concealed large-area heating on the inner wall and individual material characteristics according to STN 73 0540-3 [15]
Table 2 Mathematical-physical model of large-area radiant heating for inner (internal) wall [15]

\begin{tabular}{|c|c|c|c|c|c|}
\hline \multirow{2}{*}{ 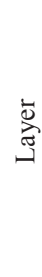 } & Material & 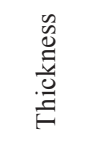 & 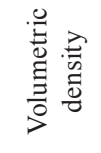 & 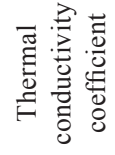 & 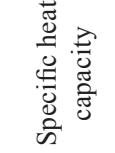 \\
\hline & & $\begin{array}{c}d \\
(\mathrm{~m})\end{array}$ & $\begin{array}{c}\rho \\
\left(\mathrm{kg} / \mathrm{m}^{3}\right)\end{array}$ & $\begin{array}{c}\lambda \\
(\mathrm{W} / \\
(\mathrm{m} \cdot \mathrm{K}))\end{array}$ & $\begin{array}{c}c \\
(\mathrm{~J} /(\mathrm{kg} . \mathrm{K}))\end{array}$ \\
\hline 1 & Interior plaster & $0.010^{*}$ & 1600 & 1.160 & 840 \\
\hline 2 & Brick masonry & 0.240 & 1350 & 0.510 & 960 \\
\hline 3 & Exterior plaster & 0.010 & 1300 & 0.800 & 840 \\
\hline
\end{tabular}

In Table 2 the values of physical quantities in individual layers of the building structure are given.

\subsubsection{Perimeter (external) wall with ITAP panel}

Legend for Fig. 3:

$L$ is tube spacing (m), DN is tube dimension (m), $\theta_{m}$ is mean temperature of heating medium $\left({ }^{\circ} \mathrm{C}\right), \theta_{i}$ is interior temperature $\left({ }^{\circ} \mathrm{C}\right), \theta_{e}$ is exterior temperature $\left({ }^{\circ} \mathrm{C}\right), \theta_{p}$ is surface temperature of heating/cooling surface $\left({ }^{\circ} \mathrm{C}\right), q_{i}$ is heat output of the heating surface towards the interior $\left(\mathrm{W} / \mathrm{m}^{2}\right), q_{e}$ is heat output of the heating surface towards the exterior $\left(\mathrm{W} / \mathrm{m}^{2}\right)$.

In Table 3 the values of physical quantities in individual layers of the building structure are given.

\subsubsection{Inner (internal) wall with ITAP panel}

Legend for Fig. 4:

$L$ is tube spacing (m), DN is tube dimension (m), $\theta_{m}$ is mean temperature of heating medium $\left({ }^{\circ} \mathrm{C}\right), \theta_{i}$ is interior temperature $\left({ }^{\circ} \mathrm{C}\right), \theta_{i 2}$ is interior temperature in the adjacent room $\left({ }^{\circ} \mathrm{C}\right), \theta_{p}$ is surface temperature of heating/cooling surface $\left({ }^{\circ} \mathrm{C}\right), q_{i}$ is heat output of the heating surface towards the interior $\left(\mathrm{W} / \mathrm{m}^{2}\right), q_{i 2}$ is heat output of the heating surface towards the adjacent room $\left(\mathrm{W} / \mathrm{m}^{2}\right)$.

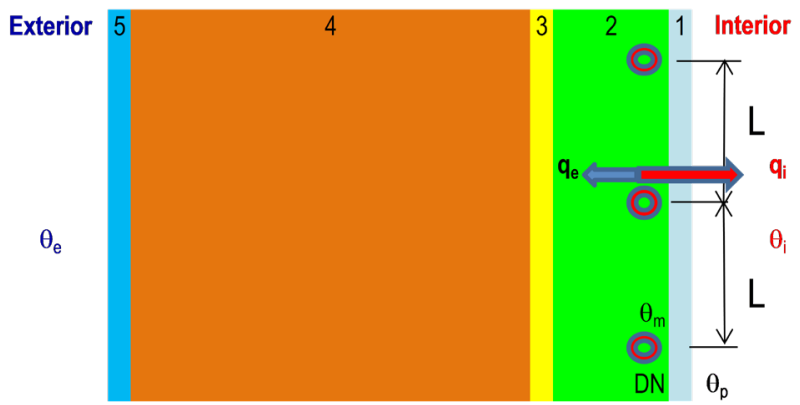

Fig. 3 Mathematical-physical model for a perimeter wall with ITAP panel and individual material characteristics according to STN 73 0540-3 [15] 
Table 3 Mathematical-physical model of large-area radiant heating for perimeter (external) wall with ITAP panel [15]

\begin{tabular}{|c|c|c|c|c|c|}
\hline 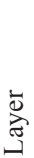 & Material & 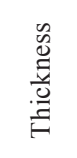 & 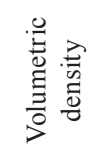 & 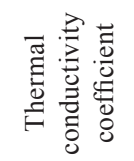 & 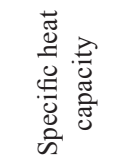 \\
\hline & & $\begin{array}{c}d \\
(\mathrm{~m})\end{array}$ & $\begin{array}{c}\rho \\
\left(\mathrm{kg} / \mathrm{m}^{3}\right)\end{array}$ & $\begin{array}{c}\lambda \\
(\mathrm{W} /(\mathrm{m} \cdot \mathrm{K}))\end{array}$ & $\begin{array}{c}c \\
(\mathrm{~J} /(\mathrm{kg} . \mathrm{K}))\end{array}$ \\
\hline 1 & Interior plaster & 0.010 & 1600 & 1.160 & 840 \\
\hline 2 & $\begin{array}{c}\text { Thermal } \\
\text { insulation EPS-F }\end{array}$ & 0.050 & 30 & 0.040 & 1270 \\
\hline 3 & Adhesive mortar & 0.005 & 1300 & 1.160 & 840 \\
\hline 4 & $\begin{array}{c}\text { Thermal insul. } \\
\text { masonry }\end{array}$ & 0.500 & 650 & 0.058 & 1000 \\
\hline 5 & Exterior plaster & 0.010 & 1300 & 0.800 & 840 \\
\hline
\end{tabular}

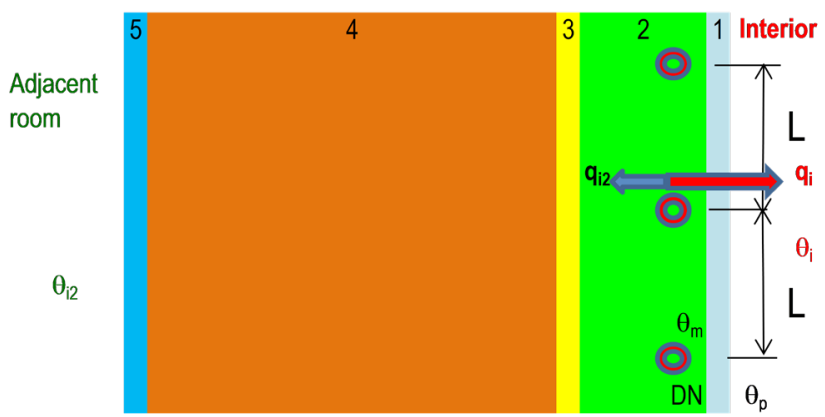

Fig. 4 Mathematical-physical model for a inner wall with ITAP panel and individual material characteristics according to STN 73 0540-3 [15]

Table 4 Mathematical-physical model of large-area radiant heating for inner (internal) wall with ITAP panel [15]

\begin{tabular}{|c|c|c|c|c|c|}
\hline 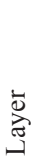 & Material & 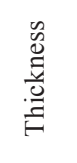 & 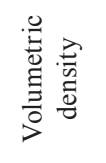 & 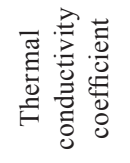 & 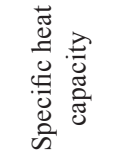 \\
\hline & & $\begin{array}{l}d \\
(\mathrm{~m})\end{array}$ & $\begin{array}{c}\rho \\
\left(\mathrm{kg} / \mathrm{m}^{3}\right)\end{array}$ & $\begin{array}{c}\lambda \\
(\mathrm{W} /(\mathrm{m} \cdot \mathrm{K}))\end{array}$ & $\begin{array}{c}c \\
(\mathrm{~J} /(\mathrm{kg} \cdot \mathrm{K}))\end{array}$ \\
\hline 1 & Interior plaster & 0.010 & 1600 & 1.160 & 840 \\
\hline 2 & $\begin{array}{l}\text { Thermal } \\
\text { insulation EPS-F }\end{array}$ & 0.050 & 30 & 0.040 & 1270 \\
\hline 3 & Adhesive mortar & 0.005 & 1300 & 1.160 & 840 \\
\hline 4 & Brick masonry & 0.240 & 1350 & 0.510 & 960 \\
\hline 5 & Exterior plaster & 0.010 & 1300 & 0.800 & 840 \\
\hline
\end{tabular}

In Table 4 the values of physical quantities in individual layers of the building structure are given.

\subsection{Parametric study}

Parametric study for the described mathematical-physical model - fragment of an inner wall with ITAP panel (Fig.4) and a perimeter wall with ITAP panel (Fig. 3) was performed on a mathematical configurator - Calculation of large-area radiant heating (VVSV) in MS Excel [15]. Input data that can be changed: thickness of thermal insulation (ITAP panel), spacing and dimensions of tubes, temperature gradient of heat transfer medium and temperature in the interior, exterior, or adjacent room, compositions and thicknesses of building structures in front of/above and behind/under tubes, thermal-technical properties of building materials (thermal conductivity of materials, heat transfer coefficient). Parametric calculations were performed at boundary conditions representing winter $\theta_{e}=-11{ }^{\circ} \mathrm{C}$ and summer $\theta_{e}=+32^{\circ} \mathrm{C}$.

Table 1 shows the input criteria for the parametric study of a perimeter wall with ITAP panels - heating period: thermal insulation thickness $50 \mathrm{~mm}$, tube dimension $15 \mathrm{~mm}$, interior temperature $+20^{\circ} \mathrm{C}$, exterior temperature $-11^{\circ} \mathrm{C}$, mean heat transfer medium temperature $+35^{\circ} \mathrm{C}$ and tube spacing $100 \mathrm{~mm}$. Using the mathematical configurator, the following parameters of large-area wall heating with ITAP panels on the perimeter wall were calculated. Outputs from the mathematical configurator - parametric study of the ITAP panel - heating period are given in Tables 5 to 7 .

\subsubsection{Winter season (heating period)}

These are important results excluded from Tables 5 to 7:

- heat flow to the interior $q_{i}=99.685 \mathrm{~W} / \mathrm{m}^{2}$,

- heat flow to the exterior $q_{e}=4.282 \mathrm{~W} / \mathrm{m}^{2}$,

- total heat flow $103.967 \mathrm{~W} / \mathrm{m}^{2}$,

- total heat flow losses $4.12 \%$,

- surface temperature $30.310{ }^{\circ} \mathrm{C}$.

Tables 8 to 10 shows the input criteria for the parametric study of a perimeter wall with ITAP panels - summer: thermal insulation thickness $50 \mathrm{~mm}$, tube dimension $15 \mathrm{~mm}$, interior temperature $+26^{\circ} \mathrm{C}$, exterior temperature $+32{ }^{\circ} \mathrm{C}$, mean temperature of the heat transfer medium is $+17{ }^{\circ} \mathrm{C}$, tube spacing $100 \mathrm{~mm}$. Using the mathematical configurator, the following parameters of large-area wall cooling with ITAP panels on the perimeter wall were calculated. Outputs from the mathematical configuratorparametric study of the ITAP panel - summer season are given in Table 8 to 10 .

\subsubsection{Summer season}

These are important results excluded from Tables 8 to 10:

- heat flow to the interior $q_{i}=-59.811 \mathrm{~W} / \mathrm{m}^{2}$,

- heat flow to the exterior $q_{e}=-1.318 \mathrm{~W} / \mathrm{m}^{2}$,

- total heat flow $-61.129 \mathrm{~W} / \mathrm{m}^{2}$,

- total heat flow losses $2.16 \%$,

- surface temperature $19.814^{\circ} \mathrm{C}$. 
Table 5 Calculation of thermal permeability of the layer above/in front of the tubes towards the interior [15]

\begin{tabular}{|c|c|c|}
\hline Name of the quantity & Value & \\
\hline Dimension of tubes $d(\mathrm{~m})$ & 0.015 & \\
\hline Thickness of the layer before/above tubes toward the interior No.1 $a_{1}(\mathrm{~m})$ & 0.018 & \\
\hline Thermal conductivity of the material in front of/above the tubes of the respective layer toward the interior No.1 $\lambda_{d 1}\left(\mathrm{~W} /\left(\mathrm{m}^{2} . \mathrm{K}\right)\right)$ & 1.160 & \\
\hline Thickness of the layer before/above tubes toward the interior No.2 $a_{2}(\mathrm{~m})$ & 0.000 & \\
\hline Thermal conductivity of the material in front of/above the tubes of the respective layer toward the interior No.2 $\lambda_{d 2}\left(\mathrm{~W} /\left(\mathrm{m}^{2} . \mathrm{K}\right)\right)$ & 0.000 & \\
\hline Heat transfer coefficient in front of/above the tubes toward the interior floor heating $h_{p i}\left(\mathrm{~W} /\left(\mathrm{m}^{2} . \mathrm{K}\right)\right)$ & 9.600 & \\
\hline Heat transfer coefficient in front of/above the tubes toward the interior ceiling heating $h_{p i}\left(\mathrm{~W} /\left(\mathrm{m}^{2} . \mathrm{K}\right)\right)$ & 7.300 & \\
\hline Name of the quantity & Value & \\
\hline Heat transfer coefficient in front of/above the tubes toward the interior wall heating $h_{p i}\left(\mathrm{~W} /\left(\mathrm{m}^{2} . \mathrm{K}\right)\right)$ & 10.000 & \\
\hline Thermal permeability in front of/above the tubes towards the interior floor heating $\Lambda_{a}\left(\mathrm{~W} /\left(\mathrm{m}^{2} . \mathrm{K}\right)\right)$ & 7.954 & \\
\hline Thermal permeability in front of/above the tubes towards the interior ceiling heating $\Lambda_{a}\left(\mathrm{~W} /\left(\mathrm{m}^{2} . \mathrm{K}\right)\right)$ & 6.308 & \\
\hline Thermal permeability in front of/above the tubes towards the interior wall heating $\Lambda_{a}\left(\mathrm{~W} /\left(\mathrm{m}^{2} . \mathrm{K}\right)\right)$ & 8.227 & \\
\hline \multicolumn{3}{|l|}{ Heat transfer efficiency } \\
\hline \multirow{3}{*}{ Ratio between the heat flow to the interior and the total heat flow, efficiency of transfer of the end radiant surfaces } & floor heating & $95.73 \%$ \\
\hline & ceiling heating & $94.51 \%$ \\
\hline & wall heating & $95.88 \%$ \\
\hline \multicolumn{3}{|l|}{ Heat loss } \\
\hline \multirow{3}{*}{$\begin{array}{l}\text { Ratio between heat flow to the exterior } \\
\text { and total heat flow - loss }\end{array}$} & floor heating & $4.27 \%$ \\
\hline & ceiling heating & $5.49 \%$ \\
\hline & wall heating & $4.12 \%$ \\
\hline
\end{tabular}

Table 6 Calculation of thermal permeability of the layer under/behind the tubes towards the exterior [15]

\begin{tabular}{|c|c|}
\hline Name of the quantity & Value \\
\hline Dimension of tubes $d(\mathrm{~m})$ & 0.015 \\
\hline Thickness of the layer behind the tubes toward the exterior No.1 $b_{1}(\mathrm{~m})$ & 0.050 \\
\hline Thermal conductivity of the respective layer of material behind/under the tubes toward the exterior No.1 $\lambda_{1}\left(\mathrm{~W} /\left(\mathrm{m}^{2} . \mathrm{K}\right)\right)$ & 0.040 \\
\hline Thickness of the layer behind the tubes toward the exterior No. $2 b_{2}(\mathrm{~m})$ & 0.005 \\
\hline Thermal conductivity of the respective layer of material behind/under the tubes toward the exterior No.2 $\lambda_{2}\left(\mathrm{~W} /\left(\mathrm{m}^{2} . \mathrm{K}\right)\right)$ & 1.160 \\
\hline Thickness of the layer behind the tubes toward the exterior No.3 $b_{3}(\mathrm{~m})$ & 0.500 \\
\hline Thermal conductivity of the respective layer of material behind/under the tubes toward the exterior No.3 $\lambda_{3}\left(\mathrm{~W} /\left(\mathrm{m}^{2} . \mathrm{K}\right)\right)$ & 0.058 \\
\hline Thickness of the layer behind the tubes toward the exterior No.4 $b_{4}(\mathrm{~m})$ & 0.005 \\
\hline Thermal conductivity of the respective layer of material behind/under the tubes toward the exterior No.4 $\lambda_{4}\left(\mathrm{~W} /\left(\mathrm{m}^{2} . \mathrm{K}\right)\right)$ & 0.800 \\
\hline Thickness of the layer behind the tubes toward the exterior No.5 $b_{5}(\mathrm{~m})$ & - \\
\hline Thermal conductivity of the respective layer of material behind/under the tubes toward the exterior No.5 $\lambda_{5}\left(\mathrm{~W} /\left(\mathrm{m}^{2} . \mathrm{K}\right)\right)$ & - \\
\hline Thickness of the layer behind the tubes toward the exterior No.6 $b_{6}(\mathrm{~m})$ & - \\
\hline Thermal conductivity of the respective layer of material behind/under the tubes toward the exterior No.6 $\lambda_{6}\left(\mathrm{~W} /\left(\mathrm{m}^{2} . \mathrm{K}\right)\right)$ & - \\
\hline Heat transfer coefficient behind the tubes toward the exterior floor heating $h_{p e}\left(\mathrm{~W} /\left(\mathrm{m}^{2} . \mathrm{K}\right)\right)$ & 7.000 \\
\hline Heat transfer coefficient behind the tubes toward the exterior ceiling heating $h_{p e}\left(\mathrm{~W} /\left(\mathrm{m}^{2} . \mathrm{K}\right)\right)$ & 7.000 \\
\hline heat transfer coefficient behind the tubes toward the exterior wall heating $h_{p e}\left(\mathrm{~W} /\left(\mathrm{m}^{2} . \mathrm{K}\right)\right)$ & 7.000 \\
\hline Thermal permeability behind/under the tubes toward the exterior floor heating $\Lambda_{b}\left(\mathrm{~W} /\left(\mathrm{m}^{2} . \mathrm{K}\right)\right)$ & 0.099 \\
\hline Thermal permeability behind/under the tubes toward the exterior ceiling heating $\Lambda_{b}\left(\mathrm{~W} /\left(\mathrm{m}^{2} . \mathrm{K}\right)\right)$ & 0.099 \\
\hline Thermal permeability behind/under the tubes toward the exterior wall heating $\Lambda_{b}\left(\mathrm{~W} /\left(\mathrm{m}^{2} . \mathrm{K}\right)\right)$ & 0.099 \\
\hline
\end{tabular}


Table 7 Calculation of large-area radiant hot water heating [15]

\begin{tabular}{|c|c|}
\hline Name of the quantity & Value \\
\hline Coefficient characterizing the heating plate in terms of heat dissipation - floor heating $m\left(\mathrm{~m}^{-1}\right)$ & 17.640 \\
\hline Coefficient characterizing the heating plate in terms of heat dissipation - ceiling heating $m\left(\mathrm{~m}^{-1}\right)$ & 15.734 \\
\hline Coefficient characterizing the heating plate in terms of heat dissipation - wall heating $m\left(\mathrm{~m}^{-1}\right)$ & 17.936 \\
\hline Mean heating water temperature $\theta_{m}\left({ }^{\circ} \mathrm{C}\right)$ & 35 \\
\hline Tube spacing $L(\mathrm{~m})$ & 0.1 \\
\hline Interior temperature $\theta_{i}\left({ }^{\circ} \mathrm{C}\right)$ & 20 \\
\hline Temperature on the opposite side of the heated space (e.g. exterior temperature) $\theta_{e}\left({ }^{\circ} \mathrm{C}\right)$ & -11 \\
\hline Surface temperature - floor heating $\theta_{p}\left({ }^{\circ} \mathrm{C}\right)$ & 29.968 \\
\hline Surface temperature - ceiling heating $\theta_{p}\left({ }^{\circ} \mathrm{C}\right)$ & 27.905 \\
\hline Surface temperature - wall heating $\theta_{p}\left({ }^{\circ} \mathrm{C}\right)$ & 30.310 \\
\hline Specific heat flow to the interior - floor heating $q_{i}\left(\mathrm{~W} / \mathrm{m}^{2}\right)$ & 95.697 \\
\hline Specific heat flow to the interior - ceiling heating $q_{i}\left(\mathrm{~W} / \mathrm{m}^{2}\right)$ & 72.770 \\
\hline Specific heat flow to the interior - wall heating $q_{i}\left(\mathrm{~W} / \mathrm{m}^{2}\right)$ & 99.685 \\
\hline Specific heat flow toward the exterior - floor heating $q_{e}\left(\mathrm{~W} / \mathrm{m}^{2}\right)$ & 4.274 \\
\hline Specific heat flow toward the exterior - ceiling heating $q_{e}\left(\mathrm{~W} / \mathrm{m}^{2}\right)$ & 4.225 \\
\hline Specific heat flow toward the exterior - wall heating $q_{e}\left(\mathrm{~W} / \mathrm{m}^{2}\right)$ & 4.282 \\
\hline Total specific heat flow toward the exterior - floor heating $\left(\mathrm{W} / \mathrm{m}^{2}\right)$ & 99.971 \\
\hline Total specific heat flow toward the exterior - ceiling heating $\left(\mathrm{W} / \mathrm{m}^{2}\right)$ & 76.995 \\
\hline Total specific heat flow toward the exterior - wall heating $\left(\mathrm{W} / \mathrm{m}^{2}\right)$ & 103.967 \\
\hline
\end{tabular}

Table 8 Calculation of thermal permeability of the layer above/in front of the tubes towards the interior [15]

\begin{tabular}{|c|c|c|}
\hline Name of the quantity & Value & \\
\hline Dimension of tubes $d(\mathrm{~m})$ & 0.015 & \\
\hline Thickness of the layer before/above tubes toward the interior No.1 $a_{1}(\mathrm{~m})$ & 0.018 & \\
\hline Thermal conductivity of the material in front of/above the tubes of the respective layer toward the interior No. $1 \lambda_{d 1}\left(\mathrm{~W} /\left(\mathrm{m}^{2} . \mathrm{K}\right)\right)$ & 1.160 & \\
\hline Thickness of the layer before/above tubes toward the interior No. $2 a_{2}(\mathrm{~m})$ & 0.000 & \\
\hline Thermal conductivity of the material in front of/above the tubes of the respective layer toward the interior No. $2 \lambda_{d 2}\left(\mathrm{~W} /\left(\mathrm{m}^{2} . \mathrm{K}\right)\right)$ & 0.000 & \\
\hline Heat transfer coefficient in front of/above the tubes toward the interior floor heating $h_{p i}\left(\mathrm{~W} /\left(\mathrm{m}^{2} . \mathrm{K}\right)\right)$ & 9.600 & \\
\hline Heat transfer coefficient in front of/above the tubes toward the interior ceiling heating $h_{p i}\left(\mathrm{~W} /\left(\mathrm{m}^{2} . \mathrm{K}\right)\right)$ & 7.300 & \\
\hline Heat transfer coefficient in front of/above the tubes toward the interior wall heating $h_{p i}\left(\mathrm{~W} /\left(\mathrm{m}^{2} . \mathrm{K}\right)\right)$ & 10.000 & \\
\hline Thermal permeability in front of/above the tubes towards the interior floor heating $\Lambda_{a}\left(\mathrm{~W} /\left(\mathrm{m}^{2} . \mathrm{K}\right)\right)$ & 7.954 & \\
\hline Thermal permeability in front of/above the tubes towards the interior ceiling heating $\Lambda_{a}\left(\mathrm{~W} /\left(\mathrm{m}^{2} . \mathrm{K}\right)\right)$ & 6.308 & \\
\hline Thermal permeability in front of/above the tubes towards the interior wall heating $\Lambda_{a}\left(\mathrm{~W} /\left(\mathrm{m}^{2} . \mathrm{K}\right)\right)$ & 8.227 & \\
\hline \multicolumn{3}{|l|}{ Heat transfer efficiency } \\
\hline \multirow{3}{*}{ Ratio between the heat flow to the interior and the total heat flow, efficiency of transfer of the end radiant surfaces } & floor heating & $97.76 \%$ \\
\hline & ceiling heating & $97.14 \%$ \\
\hline & wall heating & $97.84 \%$ \\
\hline \multicolumn{3}{|l|}{ Heat loss } \\
\hline \multirow{3}{*}{ Ratio between heat flow to the exterior and total heat flow - loss } & floor heating & $2.24 \%$ \\
\hline & ceiling heating & $2.86 \%$ \\
\hline & wall heating & $2.16 \%$ \\
\hline
\end{tabular}


Table 9 Calculation of thermal permeability of the layer under/behind the tubes towards the exterior [15]

\begin{tabular}{|c|c|}
\hline Name of the quantity & Value \\
\hline Dimension of tubes $d(\mathrm{~m})$ & 0.015 \\
\hline Thickness of the layer behind the tubes toward the exterior No.1 $b_{1}(\mathrm{~m})$ & 0.050 \\
\hline Thermal conductivity of the respective layer of material behind/under the tubes toward the exterior No.1 $\lambda_{1}\left(\mathrm{~W} /\left(\mathrm{m}^{2} . \mathrm{K}\right)\right)$ & 0.040 \\
\hline Thickness of the layer behind the tubes toward the exterior No.2 $b_{2}(\mathrm{~m})$ & 0.005 \\
\hline Thermal conductivity of the respective layer of material behind/under the tubes toward the exterior No.2 $\lambda_{2}\left(\mathrm{~W} /\left(\mathrm{m}^{2} . \mathrm{K}\right)\right)$ & 1.160 \\
\hline Thickness of the layer behind the tubes toward the exterior No.3 $b_{3}(\mathrm{~m})$ & 0.500 \\
\hline Thermal conductivity of the respective layer of material behind/under the tubes toward the exterior No.3 $\lambda_{3}\left(\mathrm{~W} /\left(\mathrm{m}^{2} . \mathrm{K}\right)\right)$ & 0.058 \\
\hline Thickness of the layer behind the tubes toward the exterior No. $4 b_{4}(\mathrm{~m})$ & 0.005 \\
\hline Thermal conductivity of the respective layer of material behind/under the tubes toward the exterior No.4 $\lambda_{4}\left(\mathrm{~W} /\left(\mathrm{m}^{2} . \mathrm{K}\right)\right)$ & 0.800 \\
\hline Thickness of the layer behind the tubes toward the exterior No.5 $b_{5}(\mathrm{~m})$ & - \\
\hline Thermal conductivity of the respective layer of material behind/under the tubes toward the exterior No.5 $\lambda_{5}\left(\mathrm{~W} /\left(\mathrm{m}^{2} . \mathrm{K}\right)\right)$ & - \\
\hline Thickness of the layer behind the tubes toward the exterior No.6 $b_{6}(\mathrm{~m})$ & - \\
\hline Thermal conductivity of the respective layer of material behind/under the tubes toward the exterior No.6 $\lambda_{6}\left(\mathrm{~W} /\left(\mathrm{m}^{2} . \mathrm{K}\right)\right)$ & - \\
\hline Heat transfer coefficient behind the tubes toward the exterior floor heating $h_{p e}\left(\mathrm{~W} /\left(\mathrm{m}^{2} . \mathrm{K}\right)\right)$ & 7.000 \\
\hline Heat transfer coefficient behind the tubes toward the exterior ceiling heating $h_{p e}\left(\mathrm{~W} /\left(\mathrm{m}^{2} . \mathrm{K}\right)\right)$ & 7.000 \\
\hline heat transfer coefficient behind the tubes toward the exterior wall heating $h_{p e}\left(\mathrm{~W} /\left(\mathrm{m}^{2} . \mathrm{K}\right)\right)$ & 7.000 \\
\hline Thermal permeability behind/under the tubes toward the exterior floor heating $\Lambda_{b}\left(\mathrm{~W} /\left(\mathrm{m}^{2} \cdot \mathrm{K}\right)\right)$ & 0.099 \\
\hline Thermal permeability behind/under the tubes toward the exterior ceiling heating $\Lambda_{b}\left(\mathrm{~W} /\left(\mathrm{m}^{2} . \mathrm{K}\right)\right)$ & 0.099 \\
\hline Thermal permeability behind/under the tubes toward the exterior wall heating $\Lambda_{b}\left(\mathrm{~W} /\left(\mathrm{m}^{2} . \mathrm{K}\right)\right)$ & 0.099 \\
\hline
\end{tabular}

Table 10 Calculation of large-area radiant cooling [15]

\begin{tabular}{|c|c|}
\hline Name of the quantity & Value \\
\hline Coefficient characterizing the heating plate in terms of heat dissipation - floor heating $m\left(\mathrm{~m}^{-1}\right)$ & 17.640 \\
\hline Coefficient characterizing the heating plate in terms of heat dissipation - ceiling heating $m\left(\mathrm{~m}^{-1}\right)$ & 15.734 \\
\hline Coefficient characterizing the heating plate in terms of heat dissipation - wall heating $m\left(\mathrm{~m}^{-1}\right)$ & 17.936 \\
\hline Mean heating water temperature $\theta_{m}\left({ }^{\circ} \mathrm{C}\right)$ & 17 \\
\hline Tube spacing $L(\mathrm{~m})$ & 0.1 \\
\hline Interior temperature $\theta_{i}\left({ }^{\circ} \mathrm{C}\right)$ & 26 \\
\hline Temperature on the opposite side of the heated space (e.g. exterior temperature) $\theta_{e}\left({ }^{\circ} \mathrm{C}\right)$ & +32 \\
\hline Surface temperature - floor heating $\theta_{p}\left({ }^{\circ} \mathrm{C}\right)$ & 20.019 \\
\hline Surface temperature - ceiling heating $\theta_{p}\left({ }^{\circ} \mathrm{C}\right)$ & 21.257 \\
\hline Surface temperature - wall heating $\theta_{p}\left({ }^{\circ} \mathrm{C}\right)$ & 19.814 \\
\hline Specific heat flow to the interior - floor heating $q_{i}\left(\mathrm{~W} / \mathrm{m}^{2}\right)$ & -57.418 \\
\hline Specific heat flow to the interior - ceiling heating $q_{i}\left(\mathrm{~W} / \mathrm{m}^{2}\right)$ & -43.662 \\
\hline Specific heat flow to the interior - wall heating $q_{i}\left(\mathrm{~W} / \mathrm{m}^{2}\right)$ & -59.811 \\
\hline Specific heat flow toward the exterior - floor heating $q_{e}\left(\mathrm{~W} / \mathrm{m}^{2}\right)$ & -1.313 \\
\hline Specific heat flow toward the exterior - ceiling heating $q_{e}\left(\mathrm{~W} / \mathrm{m}^{2}\right)$ & -1.283 \\
\hline Specific heat flow toward the exterior - wall heating $q_{e}\left(\mathrm{~W} / \mathrm{m}^{2}\right)$ & -1.318 \\
\hline Total specific heat flow toward the exterior - floor heating $\left(\mathrm{W} / \mathrm{m}^{2}\right)$ & -58.731 \\
\hline Total specific heat flow toward the exterior - ceiling heating $\left(\mathrm{W} / \mathrm{m}^{2}\right)$ & -44.945 \\
\hline Total specific heat flow toward the exterior - wall heating $\left(\mathrm{W} / \mathrm{m}^{2}\right)$ & -61.129 \\
\hline
\end{tabular}




\section{Heating and cooling capacities of ITAP panels}

Using the mathematical configurator, the heating and cooling heat flows of ITAP panels made of thermal insulation expanded polystyrene EPS-F $\left(\lambda=0.04 \mathrm{~W} /\left(\mathrm{m}^{2} . \mathrm{K}\right)\right.$ with thickness $50 \mathrm{~mm}$ with tube spacing $100 \mathrm{~mm}$ were calculated (Tables 11 and 12).

When calculating the heating heat flows, we considered the mean temperature of the heating medium of $25^{\circ} \mathrm{C}$, $30{ }^{\circ} \mathrm{C}, 35^{\circ} \mathrm{C}, 40^{\circ} \mathrm{C}$, indoor temperatures of $16{ }^{\circ} \mathrm{C}, 18^{\circ} \mathrm{C}$, $20{ }^{\circ} \mathrm{C}, 22{ }^{\circ} \mathrm{C}, 24^{\circ} \mathrm{C}$. When calculating the cooling heat flows, we considered the mean temperature of the heating medium of $15{ }^{\circ} \mathrm{C}, 16{ }^{\circ} \mathrm{C}, 17{ }^{\circ} \mathrm{C}, 18{ }^{\circ} \mathrm{C}$, indoor temperatures of $20{ }^{\circ} \mathrm{C}, 22{ }^{\circ} \mathrm{C}, 24{ }^{\circ} \mathrm{C}, 25^{\circ} \mathrm{C}, 26^{\circ} \mathrm{C}$. In addition to heat flows to the interior, exterior, and total heat flow, the surface temperature of ITAP panels was also determined.

Table 11 Heating and cooling heat flows of ITAP panels Heating period $\theta_{e}=-11^{\circ} \mathrm{C}[15]$

\begin{tabular}{|c|c|c|c|c|c|c|}
\hline \multicolumn{2}{|c|}{ Interior temperature $\theta_{i}\left({ }^{\circ} \mathrm{C}\right)$} & 16 & 18 & 20 & 22 & 24 \\
\hline \multirow{4}{*}{ 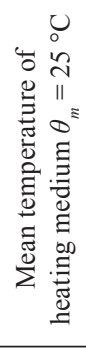 } & $\begin{array}{l}\text { Heat flow to the } \\
\text { interior } q_{i}\left(\mathrm{~W} / \mathrm{m}^{2}\right)\end{array}$ & 59.81 & 46.52 & 33.23 & 19.94 & 6.65 \\
\hline & $\begin{array}{l}\text { Heat flow to the } \\
\text { exterior } q_{e}\left(\mathrm{~W} / \mathrm{m}^{2}\right)\end{array}$ & 3.40 & 3.44 & 3.48 & 3.52 & 3.56 \\
\hline & $\begin{array}{c}\text { Total heat flow } \\
q_{\text {total }}\left(\mathrm{W} / \mathrm{m}^{2}\right)\end{array}$ & 63.22 & 49.96 & 36.71 & 23.46 & 10.20 \\
\hline & $\begin{array}{c}\text { Surface } \\
\text { temperature } \theta_{p}\left({ }^{\circ} \mathrm{C}\right)\end{array}$ & 22.19 & 22.81 & 23.44 & 24.06 & 24.69 \\
\hline \multirow{4}{*}{ 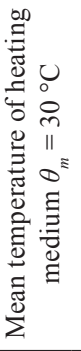 } & $\begin{array}{l}\text { Heat flow to the } \\
\text { interior } q_{i}\left(\mathrm{~W} / \mathrm{m}^{2}\right)\end{array}$ & 93.04 & 79.75 & 66.46 & 53.17 & 39.87 \\
\hline & $\begin{array}{l}\text { Heat flow to the } \\
\text { exterior } q_{e}\left(\mathrm{~W} / \mathrm{m}^{2}\right)\end{array}$ & 3.81 & 3.84 & 3.88 & 3.92 & 3.96 \\
\hline & $\begin{array}{l}\text { Total heat flow } q_{\text {total }} \\
\qquad\left(\mathrm{W} / \mathrm{m}^{2}\right)\end{array}$ & 96.84 & 83.59 & 70.34 & 57.08 & 43.83 \\
\hline & $\begin{array}{l}\text { Surface temperature } \\
\qquad \theta_{p}\left({ }^{\circ} \mathrm{C}\right) \\
\end{array}$ & 25.62 & 26.25 & 26.87 & 27.50 & 28.12 \\
\hline \multirow{4}{*}{ 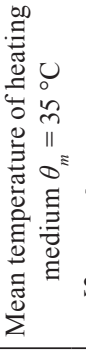 } & $\begin{array}{l}\text { Heat flow to the } \\
\text { interior } q_{i}\left(\mathrm{~W} / \mathrm{m}^{2}\right)\end{array}$ & 126.27 & 112.98 & 99.69 & 86.39 & 73.10 \\
\hline & $\begin{array}{l}\text { Heat flow to the } \\
\text { exterior } q_{e}\left(\mathrm{~W} / \mathrm{m}^{2}\right)\end{array}$ & 4.61 & 4.22 & 4.28 & 4.32 & 4.36 \\
\hline & $\begin{array}{l}\text { Total heat flow } q_{\text {total }} \\
\qquad\left(\mathrm{W} / \mathrm{m}^{2}\right)\end{array}$ & 130.87 & 117.20 & 103.97 & 90.71 & 77.46 \\
\hline & $\begin{array}{l}\text { Surface temperature } \\
\qquad \theta_{p}\left({ }^{\circ} \mathrm{C}\right)\end{array}$ & 29.06 & 29.69 & 30.31 & 30.94 & 31.56 \\
\hline \multirow{4}{*}{ 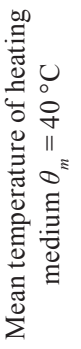 } & $\begin{array}{l}\text { Heat flow to the } \\
\text { interior } q_{i}\left(\mathrm{~W} / \mathrm{m}^{2}\right)\end{array}$ & 159.50 & 146.21 & 132.91 & 119.62 & 106.33 \\
\hline & $\begin{array}{l}\text { Heat flow to the } \\
\text { exterior } q_{e}\left(\mathrm{~W} / \mathrm{m}^{2}\right)\end{array}$ & 4.61 & 4.65 & 4.68 & 4.72 & 4.76 \\
\hline & $\begin{array}{l}\text { Total heat flow } q_{\text {total }} \\
\qquad\left(\mathrm{W} / \mathrm{m}^{2}\right)\end{array}$ & 164.10 & 150.85 & 137.60 & 124.34 & 111.09 \\
\hline & $\begin{array}{l}\text { Surface temperature } \\
\qquad \theta_{p}\left({ }^{\circ} \mathrm{C}\right)\end{array}$ & 32.50 & 33.12 & 33.75 & 34.37 & 35.00 \\
\hline
\end{tabular}

Table 12 Heating and cooling heat flows of ITAP panels Summer period $\theta_{e}=+32{ }^{\circ} \mathrm{C}[15]$

\begin{tabular}{|c|c|c|c|c|c|c|}
\hline \multicolumn{2}{|c|}{ Interior temperature $\theta_{i}\left({ }^{\circ} \mathrm{C}\right)$} & 20 & 22 & 24 & 25 & 26 \\
\hline $\begin{array}{l}0 \\
0 \\
4 \\
0\end{array}$ & $\begin{array}{l}\text { Heat flow to the } \\
\text { interior } q_{i}\left(\mathrm{~W} / \mathrm{m}^{2}\right)\end{array}$ & -33.23 & -46.52 & -59.81 & -66.46 & -73.10 \\
\hline 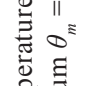 & $\begin{array}{l}\text { Heat flow to the } \\
\text { exterior } q_{e}\left(\mathrm{~W} / \mathrm{m}^{2}\right)\end{array}$ & -1.59 & -1.56 & -1.52 & -1.50 & -1.48 \\
\hline 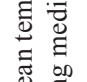 & $\begin{array}{c}\text { Total heat flow } \\
q_{\text {total }}\left(\mathrm{W} / \mathrm{m}^{2}\right)\end{array}$ & -34.82 & -48.08 & -61.33 & -67.95 & -74.58 \\
\hline$\sum \frac{7}{8}$ & $\begin{array}{c}\text { Surface } \\
\text { temperature } \theta_{p}\left({ }^{\circ} \mathrm{C}\right)\end{array}$ & 16.56 & 17.19 & 17.81 & 18.13 & 18.44 \\
\hline $\begin{array}{l}0 \\
0 \\
0 \\
0\end{array}$ & $\begin{array}{l}\text { Heat flow to the } \\
\text { interior } q_{i}\left(\mathrm{~W} / \mathrm{m}^{2}\right)\end{array}$ & -26.58 & -39.87 & -53.17 & -59.81 & -66.46 \\
\hline 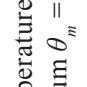 & $\begin{array}{l}\text { Heat flow to the } \\
\text { exterior } q_{e}\left(\mathrm{~W} / \mathrm{m}^{2}\right)\end{array}$ & -1.51 & -1.48 & -1.44 & -1.42 & -1.40 \\
\hline 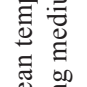 & $\begin{array}{c}\text { Total heat flow } \\
q_{\text {total }}\left(\mathrm{W} / \mathrm{m}^{2}\right)\end{array}$ & -28.10 & -41.35 & -54.60 & -61.23 & -67.86 \\
\hline$\sum \frac{7}{8}$ & $\begin{array}{c}\text { Surface } \\
\text { temperature } \theta_{p}\left({ }^{\circ} \mathrm{C}\right)\end{array}$ & 17.25 & 17.88 & 18.50 & 18.81 & 19.13 \\
\hline $\begin{array}{l}0 \\
0 \\
0\end{array}$ & $\begin{array}{l}\text { Heat flow to the } \\
\text { interior } q_{i}\left(\mathrm{~W} / \mathrm{m}^{2}\right)\end{array}$ & -19.94 & -33.23 & -46.52 & -53.17 & -59.81 \\
\hline 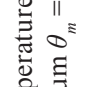 & $\begin{array}{l}\text { Heat flow to the } \\
\text { exterior } q_{e}\left(\mathrm{~W} / \mathrm{m}^{2}\right)\end{array}$ & -1.43 & -1.39 & -1.36 & -1.34 & -1.32 \\
\hline 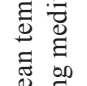 & $\begin{array}{c}\text { Total heat flow } \\
q_{\text {total }}\left(\mathrm{W} / \mathrm{m}^{2}\right)\end{array}$ & -21.37 & -34.62 & -47.88 & -54.50 & -61.13 \\
\hline$\sum \underset{0}{\nexists j}$ & $\begin{array}{c}\text { Surface } \\
\text { temperature } \theta_{p}\left({ }^{\circ} \mathrm{C}\right)\end{array}$ & 17.94 & 18.56 & 19.19 & 19.50 & 19.81 \\
\hline $\begin{aligned} & 0 \\
0 & \infty \\
& \infty\end{aligned}$ & $\begin{array}{l}\text { Heat flow to the } \\
\text { interior } q_{i}\left(\mathrm{~W} / \mathrm{m}^{2}\right)\end{array}$ & -13.29 & -26.58 & -39.87 & -46.52 & -53.17 \\
\hline 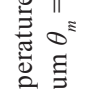 & $\begin{array}{l}\text { Heat flow to the } \\
\text { exterior } q_{e}\left(\mathrm{~W} / \mathrm{m}^{2}\right)\end{array}$ & -1.35 & -1.31 & -1.28 & -1.26 & -1.24 \\
\hline 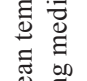 & $\begin{array}{l}\text { Total heat flow } \\
q_{\text {total }}\left(\mathrm{W} / \mathrm{m}^{2}\right)\end{array}$ & -14.64 & -27.90 & -41.15 & -47.78 & -54.40 \\
\hline$\sum \begin{array}{l}\Sigma \\
0 \\
0\end{array}$ & $\begin{array}{c}\text { Surface } \\
\text { temperature } \theta_{p}\left({ }^{\circ} \mathrm{C}\right)\end{array}$ & 18.63 & 19.25 & 19.88 & 20.19 & 20.50 \\
\hline
\end{tabular}

\section{Discussion}

Based on mathematical-physical models for concealed large-area radiant heating/cooling and for ITAP panels, a comparison of these two energy systems on the perimeter wall and on the inner wall of a building was performed for the following boundary conditions: mean temperature of heat transfer medium for heating is $+35{ }^{\circ} \mathrm{C}$, for cooling medium it is $+17^{\circ} \mathrm{C}$, indoor temperature in the heating season is $+20^{\circ} \mathrm{C}$, in the summer it is $+26^{\circ} \mathrm{C}$, outdoor temperature in the heating season is $-11{ }^{\circ} \mathrm{C}$, in the summer $+32{ }^{\circ} \mathrm{C}$, room temperature behind the inner wall is $+18{ }^{\circ} \mathrm{C}$ (winter) and $+26{ }^{\circ} \mathrm{C}$ (summer), tube spacing is $L=100 \mathrm{~mm}$, thickness of thermal insulation part of ITAP panel is $50 \mathrm{~mm}$ (EPS-F). 
It can be stated (Tables 13 to 14), that the application of large-area radiant heating/cooling of under plaster and using ITAP panels on perimeter walls (the composition meets the requirements of STN EN 730540 [8], $U=0.22 \mathrm{~W} /\left(\mathrm{m}^{2} . \mathrm{K}\right)$ ) in terms of energy show almost the same heating and cooling heat fluxes.

When applying large-area concealed radiant heating/ cooling and ITAP panels on internal walls (thickness of ceramic bricks $240 \mathrm{~mm}$, thermal conductivity of the material $\left.0.510 \mathrm{~W} /\left(\mathrm{m}^{2} . \mathrm{K}\right)\right)$, which have worse thermal resistance than perimeter walls, ITAP panels show heating saving of approximately $13 \%$ and for cooling of approximately $11 \%$ compared to a concealed tube energy system thanks to thermal insulation, which adjusts the thermal permeability of the wall layers behind the tubes towards the adjacent room $\Lambda_{b}\left(\mathrm{~W} /\left(\mathrm{m}^{2} . \mathrm{K}\right)\right)$. In addition to these savings, it is clear from Tables 15 and 16 that the ratio of heat flow towards the heated/cooled space is 78:22 for concealed pipe system with heating and 81:19 for cooling. The heat flow ratio towards the heated/cooled space is 93:7 for ITAP panels for heating and 94:6 for cooling.

Legend for Tables 13 to 14:

$\Lambda_{a}$ is thermal permeability in front of/above the tubes towards the interior $\left(\mathrm{W} /\left(\mathrm{m}^{2} . \mathrm{K}\right)\right), \Lambda_{b}$ is thermal permeability behind/under the tubes towards the exterior $\left(\mathrm{W}\left(\mathrm{m}^{2} . \mathrm{K}\right)\right)$, $\theta_{p}$ is surface temperature of heating/cooling surface $\left({ }^{\circ} \mathrm{C}\right)$, $\theta_{i}$ is specific heat flow to the interior $\left(\mathrm{W} / \mathrm{m}^{2}\right), \theta_{e}$ is specific heat flow to the exterior $\left(\mathrm{W} / \mathrm{m}^{2}\right), q_{\text {total }}$ is total specific heat flow $\left(\mathrm{W} / \mathrm{m}^{2}\right)$.

Legend for Tables 15 and 16:

$\Lambda_{a}$ is thermal permeability in front of/above the tubes towards the interior $\left(\mathrm{W} /\left(\mathrm{m}^{2} . \mathrm{K}\right)\right), \Lambda_{b}$ is thermal permeability behind/under the tubes towards the exterior (W/ $\left.\left(\mathrm{m}^{2} . \mathrm{K}\right)\right), \theta_{p}$ is surface temperature of heating/cooling surface $\left({ }^{\circ} \mathrm{C}\right), \theta_{i}$ is specific heat flow to the interior $\left(\mathrm{W} / \mathrm{m}^{2}\right), \theta_{e}$ is specific heat flow to the exterior $\left(\mathrm{W} / \mathrm{m}^{2}\right), q_{\text {total }}$ is total specific heat flow $\left(\mathrm{W} / \mathrm{m}^{2}\right)$.

\section{Conclusions}

Based on the parametric study of ITAP panels and the concealed tubular energy system on the perimeter wall and the inner wall between two rooms, it was determined that:

- The thickness of thermal insulation of ITAP panels when applied to perimeter walls (the composition meets the requirements of STN EN 730540 [8], max. $U=0.22$ $\mathrm{W} /\left(\mathrm{m}^{2} . \mathrm{K}\right)$ has almost no effect in terms of energy requirements. Thermal heating and cooling flows are approximately the same as with the concealed tube system.

- When applying large-area radiant heating/cooling with a concealed tubular energy system and ITAP panels on interior walls that have worse thermal resistance than perimeter walls, ITAP panels show savings in heating and

Table 13 Comparison of heating and cooling heat flows - perimeter wall Wall heating [15]

\begin{tabular}{|c|c|c|c|c|c|c|c|c|}
\hline Boundary conditions & & & $\Lambda_{a}$ & $\Lambda_{b}$ & $\theta_{p}$ & $\theta_{i}$ & $\theta_{e}$ & $q_{\text {total }}$ \\
\hline Interior temperature $\theta_{i}\left({ }^{\circ} \mathrm{C}\right)$ & 20 & 巳 苛 & & & & & & \\
\hline Exterior temperature $\theta_{e}\left({ }^{\circ} \mathrm{C}\right)$ & -11 & 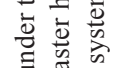 & 8.227 & 0.116 & 30.30 & 99.64 & 4.99 & 104.63 \\
\hline Mean temperature of heating medium $\theta_{m}\left({ }^{\circ} \mathrm{C}\right)$ & 35 & $=\frac{\pi}{2}$ & & & & & & losses $4.77 \%$ \\
\hline Tube spacing $L(\mathrm{~mm})$ & 100 & $\bar{\Xi}$ & & & & & & \\
\hline Tube diameter (mm) & 15 & $\underset{2}{\stackrel{\pi}{2}}$ & 8.227 & 0.099 & 30.31 & 99.68 & 4.28 & 103.96 \\
\hline Thermal insulation thickness - ITAP (mm) & 50 & 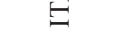 & & & & & & losses $4.12 \%$ \\
\hline
\end{tabular}

Table 14 Comparison of heating and cooling heat flows - perimeter wall Wall cooling [15]

\begin{tabular}{|c|c|c|c|c|c|c|c|c|}
\hline Boundary conditions & & & $\Lambda_{a}$ & $\Lambda_{b}$ & $\theta_{p}$ & $\theta_{i}$ & $\theta_{e}$ & $q_{\text {total }}$ \\
\hline Interior temperature $\theta_{i}\left({ }^{\circ} \mathrm{C}\right)$ & 26 & $\stackrel{\dot{\circ}}{\nsubseteq} \Xi$ & & & & & & \\
\hline Exterior temperature $\theta_{e}\left({ }^{\circ} \mathrm{C}\right)$ & +32 & 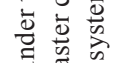 & 8.227 & 0.116 & 19.81 & -59.78 & -1.53 & -61.32 \\
\hline Mean temperature of heating medium $\theta_{m}\left({ }^{\circ} \mathrm{C}\right)$ & 17 & $=\frac{\pi}{2}$ & & & & & & losses $2.50 \%$ \\
\hline Tube spacing $L(\mathrm{~mm})$ & 100 & $\bar{\Xi}$ & & & & & & \\
\hline Tube diameter (mm) & 15 & $\stackrel{2}{2}$ & 8.227 & 0.099 & 19.81 & -59.81 & -1.31 & -61.12 \\
\hline Thermal insulation thickness - ITAP (mm) & 50 & 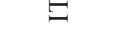 & & & & & & losses $2.16 \%$ \\
\hline
\end{tabular}


Table 15 Comparison of heating and cooling heat flows inner wall - Wall heating [15]

\begin{tabular}{|c|c|c|c|c|c|c|c|c|}
\hline Boundary conditions & & & $\Lambda_{a}$ & $\Lambda_{b}$ & $\theta_{p}$ & $\theta_{i}$ & $\theta_{e}$ & $q_{\text {total }}$ \\
\hline Interior temperature $\theta_{i}\left({ }^{\circ} \mathrm{C}\right)$ & 20 & $\cong \stackrel{\Xi}{\Xi} \Xi$ & & & & & & \\
\hline Exterior temperature $\theta_{e}\left({ }^{\circ} \mathrm{C}\right)$ & -11 & 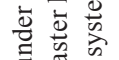 & 8.227 & 1.963 & 31.93 & 57.33 & 17.60 & 74.943 \\
\hline Mean temperature of heating medium $\theta_{m}\left({ }^{\circ} \mathrm{C}\right)$ & 35 & $=\frac{\pi}{2}$ & & & & & & losses $23.50 \%$ \\
\hline Tube spacing $L(\mathrm{~mm})$ & 100 & $\bar{\Xi}$ & & & & & & \\
\hline Tube diameter (mm) & 15 & $\stackrel{2}{2}$ & 8.227 & 0.516 & 32.12 & 59.23 & 4.74 & 63.981 \\
\hline Thermal insulation thickness - ITAP (mm) & 50 & 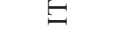 & & & & & & losses $7.42 \%$ \\
\hline
\end{tabular}

Table 16 Comparison of heating and cooling heat flows inner wall - Wall cooling [15]

\begin{tabular}{|c|c|c|c|c|c|c|c|c|}
\hline Boundary conditions & & & $\Lambda_{a}$ & $\Lambda_{b}$ & $\theta_{p}$ & $\theta_{i}$ & $\theta_{e}$ & $q_{\text {total }}$ \\
\hline Interior temperature $\theta_{i}\left({ }^{\circ} \mathrm{C}\right)$ & 26 & $\stackrel{\dot{0}}{\circ} \Xi$ & & & & & & \\
\hline Exterior temperature $\theta_{e}\left({ }^{\circ} \mathrm{C}\right)$ & +32 & 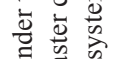 & 8.227 & 1.963 & 20.07 & -57.33 & -9.75 & -67.09 \\
\hline Mean temperature of heating medium $\theta_{m}\left({ }^{\circ} \mathrm{C}\right)$ & 17 & $=\frac{\pi}{2}$ & & & & & & losses $14.54 \%$ \\
\hline Tube spacing $L(\mathrm{~mm})$ & 100 & $\bar{\Xi}$ & & & & & & \\
\hline Tube diameter (mm) & 15 & $e^{2}$ & 8.227 & 0.516 & 19.87 & -59.23 & -2.68 & -61.91 \\
\hline Thermal insulation thickness - ITAP (mm) & 50 & 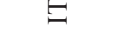 & & & & & & losses $4.33 \%$ \\
\hline
\end{tabular}

cooling compared to a concealed tubular energy system due to thermal insulation that adjusts thermal permeability of layers of the wall behind the tubes towards the adjacent room $\Lambda_{b}\left(\mathrm{~W} /\left(\mathrm{m}^{2} . \mathrm{K}\right)\right)$. In the case of the inner wall (thickness of ceramic bricks $240 \mathrm{~mm}$, thermal conductivity of the material $0.510 \mathrm{~W} /\left(\mathrm{m}^{2} . \mathrm{K}\right)$, ITAP panels show savings of approximately $13 \%$ in heating and approximately $11 \%$ in cooling.

- The mean temperature of the heat transfer medium and the interior temperature of the heated/cooled space, has a significant effect on the heating and cooling capacity of ITAP panels, as well as the concealed tubular energy system.

- Tube spacing has significant influence on the heating and cooling capacity of ITAP panels, as well as of concealed tube energy system, e.g. when spacing is changed from $L=100$ to $150 \mathrm{~mm}$, capacity is reduced by about 15 to $20 \%$ and to $L=200 \mathrm{~mm}$ capacity reduction is about 30 to $35 \%$.

- The influence of exterior temperature, respectively, temperature in the adjacent space for heating and cooling capacity of ITAP panels, as well as concealed tubular energy system, represents a deviation of about $5 \%$ depending on the thermal insulation properties of building structures on which large-area radiant energy systems are applied.

- The effect of changing the tube dimensions of ITAP panels, as well as of the concealed tube energy system, from a diameter of $d=15$ to $20 \mathrm{~mm}$ on the heating and cooling capacity represents a deviation of approximately $2.5 \%$.
The research will continue with parametric studies under other boundary conditions and search for optimal criteria for design, calculation, and assessment of energy-efficient, economically efficient and environmentally friendly large-area radiant energy systems. Another research task will be to establish criteria for ITAP panels with air as the heat-carrying medium in applications for floor, ceiling, and wall heating. After a mathematical-physical model is developed, parametric studies and mathematical simulations will be performed.

The research will also continue under laboratory conditions, where measurements will be performed on a fragment of a perimeter, interior wall, ceiling, and floor with ITAP panels and built-in tubular energy systems, as well as air ducts.

The main benefit of ITAP panels - interior thermally active panels with an integrated active area - is the possibility of unified and prefabricated production. At the same time, they represent a reduction of production costs due to their technologically simpler production process (DN of tubes for thermal insulation part of ITAP panels is not limited as for panels with pipes in SD), reduction of assembly costs due to fewer construction steps and less time needed for implementation with regard to their method of application. 


\section{Acknowledgement}

This research was supported by the Ministry of education, Science, Research and Sport of the Slovak republic grant KEGA 044STU-4/2018.

This research was supported by the Ministry of education, Science, Research and Sport of the Slovak republic grant VEGA 1/0847/18.

This research was supported by the Ministry of education, Science, Research and Sport of the Slovak republic grant VEGA 1/0303/21.

\section{References}

[1] Kalús, D. "Heat Insulating Panel with Active Regulation of Heat Transition", European Patent Office, Wien, Austria, EP 2572057 B1, 2011.

[2] Kalús, D., Straková, Z., Takács, J., Kubica, M. "Building Structures with Internal Heat Source - Heat Insulating Panels with Active Regulation of Heat Transition", International Refereed Journal of Engineering and Science, 9(5), pp. 33-40, 2020. [online] Available at: http://www.irjes.com/Papers/vol9-issue5/F09053340.pdf [Accessed: 22 November 2020]

[3] Cvíčela, M. "Analýza stenových energetických systémov" (Analysis of wall energy systems), PhD Dissertation, Slovak University of Technology in Bratislava, 2011. (in Slovakian)

[4] Janík, P. "Optimalizácia energetických systémov s dlhodobou akumuláciou tepla" (Optimization of energy systems with long-term heat accumulation), $\mathrm{PhD}$ thesis, Slovak University of Technology in Bratislava, 2013.

[5] Zhu, Q., Xu, X., Gao, J., Xiao, F. "A semi-dynamic model of active pipe-embedded building envelope for thermal performance evaluation", International Journal of Thermal Sciences, 88, pp. 170-179, 2015.

https://doi.org/10.1016/j.ijthermalsci.2014.09.014

[6] Krzaczek, M., Kowalczuk, Z. "Thermal Barrier as a technique of indirect heating and cooling for residential buildings", Energy and Buildings, 43, pp. 823-837, 2011.

https://doi.org/10.1016/j.enbuild.2010.12.002

[7] Babiak, J., Olesen, B. W., Petráš, D. "Low temperature heating and high temperature cooling", The Federation of European Heating, Federation of European Heating, Ventilation and Air Conditioning Associations (REHVA), Brussels, Belgium, 2007.

[8] Sternová, Z. "STN 73 0540-2+Z1+Z2:2019 Tepelná ochrana budov. Tepelnotechnické vlastnosti stavebných konštrukcií a budov. Čast' 2: Funkčné požiadavky. Konsolidované znenie" (Thermal protection of buildings. Thermal performance of buildings and components. Part 2: Functional requirements. Consolidated text), Slovak Office of Standards, Metrology and Testing, Bratislava, Slovakia, 2019. (in Slovakian)
This research was supported by the Ministry of education, Science, Research and Sport of the Slovak republic grant VEGA 1/0304/21.

This research was supported by the Ministry of education, Science, Research and Sport of the Slovak republic grant KEGA 005STU-4/2021.

[9] Slovak Office of Standards, Metrology and Testing "STN EN 12831-1 Energetická hospodárnost' budov. Metóda výpočtu projektovaného tepelného príkonu. Čast' 1: Tepelný príkon, Modul M3-3" (Energy performance of buildings. Method for calculation of the design heat load. Part 1: Space heating load, Module M3-3), Slovak Office of Standards, Metrology and Testing, Bratislava, Slovakia, 2019. (in Slovakian)

[10] Slovak Office of Standards, Metrology and Testing "STN 06 0312 Ústredné sálavé vykurovanie so zabetónovanými rúrkami" (Radiation central heating with concreted tubes), Slovak Office of Standards, Metrology and Testing, Bratislava, Slovakia, 1972. (in Czech)

[11] Krajčík, M., Petráš, D., Skalíková, I. "Energetické hodnotenie budov" (Energy rating of buildings), Spektrum STU, Bratislava, Slovakia, 2019. (in Slovakian)

[12] Chmúrny, I. "Tepelná ochrana budov" (Thermal protection of buildings), Jaga, Bratislava, Slovakia, 2003. (in Slovakian)

[13] Kurčová, M., Koudelková, D. "Vykurovanie" (Heating), Spektrum STU, Bratislava, Slovakia, 2020. (in Slovakian)

[14] Slovak Office of Standards, Metrology and Testing "STN 73 0540-3 Tepelnotechnické vlastnosti stavebných konštrukcií a budov. Tepelná ochrana budov. Čast' 3: Vlastnosti prostredia a stavebných výrobkov" (Thermal performance of buildings and components. Thermal protection of buildings. Part 3: Properties of environments and building products), Slovak Office of Standards, Metrology and Testing, Bratislava, Slovakia, 2002. (in Slovakian)

[15] Kalús, D. "Interiérové tepelně aktivní panely s integrovanou aktivní plochou" (Interior thermally active panels with integrated active surface), TZB Haustechnik, 9(4), pp. 38-41, 2016. (in Czech) 